\title{
Strategies and Business Models of Sharing Economy: MSMEs Digital Creativity
}

\author{
Yuni Rimawati ${ }^{1 *}$, Atik Emilia Sula ${ }^{2}$
}

\section{AFFILIATION:}

1,2Faculty of Economics and Business, Universitas Trunojoyo Madura, Indonesia

\section{*CORRESPONDENCE:}

yuni.rimawati@trunojoyo.ac.id

THIS ARTICLE IS AVAILABLE IN:

https://ojs.unud.ac.id/index.php/jiab

DOI:

10.24843/JIAB.2020.v15.i02.p04

\section{CITATION:}

Rimawati, Y., Sula, A. E. (2020). Strategies and Business Models of Sharing Economy: MSMEs Digital Creativity. Jurnal IImiah Akuntansi dan Bisnis, 15(2), 187-201.

\section{ARTICLE HISTORY}

Received:

27 November 2019

Revised:

29 May 2020

Accepted:

06 July 2020

\begin{abstract}
This study aims to explore the business strategy of Pesan Antar and present its business model by referring to the economic sharing model between Micro, Small and Medium Enterprises (MSMEs). The analysis of this study uses the ethnometodology method. The findings of this study are Pesan Antar has done a branding strategy before business activities begin. The strategy to maintain the loyalty of the courier, Pesan Antar applies a profit sharing and bonus mechanism, also implementing family culture to run business. Strategy to maintain business growth, Pesan Antar introducing other MSME products (though not yet a partner) no "fees" become a partner. To maintain customer loyalty, Pesan Antar strategy are "the rate" charged to customers is per region and order system using social media (not an application). Pesan Antar match with Type I economic models sharing among MSMEs Choi et al. (2014).
\end{abstract}

Keywords: Business strategy, economic sharing model, MSMEs, digital creativity.

\section{Introduction}

Salim \& Ihalauw (2017), explain that Gojek has led to a new economic movement called the sharing economy, also known as a collaborative economy or shared economy. Application of technology and communication (ICT) which is owned by Gojek facilitates communication and transactions (Anwar et al., 2015; Detikfinace, 2019). This transaction becomes economic-sharing for customers because they get access that facilitates the fulfillment of needs at competitive prices. Gojek as the application owner "feels" the economy-sharing the percentage of profits from existing transactions. Besides, the economy of sharing is also felt by the drivers and those who "hold their wares" on the Gojek application. The developments and services offered by Gojek inspire similar services in several areas not yet served by Gojek (Muhktar \& Muchammad, 2011; Paquette, 2018).

One of the Gojek services is Go-Food. Inspired by the service, Agus Josiandi opened a similar but not the same business, namely "Pesan Antar" in Bangkalan (Christian, 2015; Eko, 2018). The initial existence of Gojek was aimed at serving the transportation of the people of Jakarta (big city, public transportation facilities are actually very attentive, there 


\section{Rimawati \& Sula \\ Strategies and Business Models of Sharing Economy: MSMEs Digital Creativity}

have been conventional motorcycle taxi services) by utilizing application in smart phone (Ihsannudin, 2011). Whereas Pesan Antar by utilizing social media, its core business is delivering goods (not for human transportation) (Hendrastomo et al., 2016).

Suprijati \& Yakin (2017), state that the construction of the Suramadu Bridge still does not have a full impact on the economy of the Bangkalan Regency. This is because based on Harrod-Domar theory analysis, the average actual growth $(\mathrm{Gn})$ is greater than average warranted growth (Gw) or Gn 12.02\%> GW 5.9\% (Suprijati \& Yakin, 2017), Furthermore based on data of Bangkalan in numbers (BPS, 2017), from 473,411 workforce in 2014, there were open unemployment of 17,032 men and 9,862 women, while the labor force in 2015 was 481,352 of that number unemployed men amounted to 13,570 and women amounted to 10,500 . This unemployment rate was very large at $17.6 \%$ in 2014 and increased to $19.99 \%$ in 2015.

High unemployment rates and glittering transportation access to and from Bangkalan with the existence of Suramadu bridge, open access to "trying" both in positive and negative side. What is meant by a positive "try" here is the better transportation access from and to Bangkalan, opening opportunities for people to "do business" (read: entrepreneur and even entrepreneurship). While the negative side referred to above is that the operation of the Suramadu Bridge will automatically reduce the reduction in some jobs, even the existence of the Suramadu Bridge actually erodes the number of Public Passenger Cars (Maika, 2016; Tjitradi, 2015).

Motorcycle taxis' (ojek) has not yet become a transportation mode that is commonly used by the people, so this "Pesan Antar" business is a "new" service for the people of Bangkalan (Eko, 2018). In many studies, it was mentioned that the choice of being an entrepreneur is after deadlocked in meeting the economic needs and impartiality of the opportunity to work in the formal sector (Tambunan, 2009). As the name suggest "Pesan Antar", at the beginning of its establishment to provide foodpurchasing services (such as Go-Food). Seeing a large market share in the field of delivery services, then also widen services on shopping orders for kitchen and other household needs (Aldo, 2017).

At present, the number of Pesan Antar's couriers are twelve, with demographics varying by gender, age and level of education. Noted, from several couriers of Pesan Antar that dominant male sex, there is also one female courier who had joined. Whereas from the level of education, no less than five couriers of Pesan Antar are graduates of Universities with Diploma and Bachelor's degree. Pesan Antar also conducts free promotions for home industry players MSMEs where the majority of them are housewives without shops (product display place) (Osterwalder \& Pigneur, 2010; Putra, 2018).

Hendrastomo et al., (2016) have examined the contribution of online motorcycle taxis' existence socio-economically in Yogyakarta from the driver's side. While Amajida (2014), has examined the meaning of the use of online motorcycle taxis in Jakarta as a user's strategy to reduce the risks that occur in terms of uncertainty in transportation modes along with a variety of technological features that support the business. Later on, Salim \& Ihalauw (2017), explained that Gojek had brought up a new economic movement called sharing economy based on the perspective of added value and competitive advantage. In the economic model of sharing among MSMEs, Choi et al., (2014), mentioned the need for an active role of the Government especially the Regional Government in mediating cooperation schemes and other benefits. 


\section{Rimawati \& Sula \\ Strategies and Business Models of Sharing Economy: MSMEs Digital Creativity}

Indonesian Minister of Communication and Information Rudiantara said that sharing economy will grow in an economic sector that is still inefficient (Hutabarat, 2018). There have been many studies exploring ICT-based businesses but have not been found to discuss them from the perspective of (Choi et al., 2014). Choi et al., (2014), have built an economic model of sharing MSMEs with the canvas business model. By exploring the sharing economy with the model of Choi et al., (2014), it is expected to be able to understand the relevant parties and their impacts in more detail in all categories of constituents involved. The Pesan Antar as a form of creative use of information technology and entrepreneurship of "young people" not only open employment for owners and couriers (internal company) but also have an impact on the development of MSMEs in Bangkalan. That is because in promoting its services, Pesan Antar also promotes MSME products that can be purchased with its services (Safira, 2018; Yunus, 2018).

This research interest in the Pesan Antar (MSMEs) business as due to the stakeholders involved and its ability to survive until now (2019), when similar competitors and even grab have been operating in Bangkalan. Based on previous studies and preliminary observations about Pesan Antar, the purpose of this study is to explore the Pesan Antar business strategy and present the Pesan Antar business model regarding the economic sharing model between MSMEs (Choi et al., 2014)

This study expected contributions will be given in terms of theoretical and practices business strategy. The contribution of theoretical given by this study is presenting a sharing economic business model of MSMEs in Indonesia based on the economic sharing model between MSMEs developed by Choi et al., (2014). Whereas in business practice MSMEs, this study provides a "Real Example" of applying business strategies, especially business pioneering with the economic sharing concept based of information technology (social media) that is able to survive and have position. "Real Example" which is a reference for business practices in this study is pursued through the ethnometodology method. Both of these contributions become the renewal of this study.

\section{Research Method}

This study uses a qualitative method. The qualitative method was chosen because this study aims to get a "depth" understanding of the existence strategy of the "Pesan Antar" business based on the internal and external perspectives involved. Then this study constructs it on the economic sharing business model Choi et al., (2014).

Ethnomethodology approach is the approach chosen to achieve the objectives of this study. Kamayanti (2016), defines the ethnomethodology approach as "everyday activities as members" methods for making those same activities visibly rational and reportable for all practical purposes".

Referring to Kamayanti (2016), there are "keywords" that must be examined in the use of ethnomethodology. The first keyword is "everyday activities". "Everyday activities" in this study referred to how the business process of Pesan Antar. The second keyword is "members method". This study looks for the relationship of individuals (business management Pesan Antar) with their groups (not individuals) when doing their "habits", namely business activities.

The third keyword is "visibly rational and reportable for all practical purposes". This study seeks to find rational reasons for sharing economic routines carried out by 
Pesan Antar stakeholders. The fourth keyword is "accountable". Kamayanti (2016), explains what is meant by "accountable" is an activity that can be understood as an activity that is experienced and can be observed by all group members and then reproduced due to the agreement. "Accountable" in this study is a business model and sharing economy that is carried out by the Pesan Antar.

Departing from the objectives of ethnomethodology, Kamayanti (2016), explains that ethnomethodology is used because researchers look for reasons why a community/group/organization behaves with a certain rationalization structure without making improvements/solutions. As Kamayanti (2016), pointed out, if an ethnomethodologist examines LGBT behavior, then it is not allowed to justify the behavior based on God's revelation (Iqbal, 2011; Setiawan, 2019).

As a preliminary "map" in business observations of Pesan Antar, this study uses an economic sharing model between MSMEs (Choi et al., 2014). Choi et al., (2014), developed a economic sharing model among MSMEs with reference to the canvas business model. Choi et al., (2014), divide the economic sharing business model into 2 types. Type I is a type of shared economy in which excess goods and services are owned by anyone from outside the company and lent to the company. Whereas Type II is another type of sharing economy in which a company invests and shares with other companies' goods or services that are expected to be excessive if each company has it. The constituent factors of the sharing economy business model among MSMEs developed by Choi et al., (2014), are illustrated in Table 1.

Table 1. The Economic Sharing Business Model of MSMEs

\begin{tabular}{|c|c|c|}
\hline \multirow{2}{*}{ Category } & \multicolumn{2}{|c|}{ Class Type } \\
\hline & Type I & Type II \\
\hline Value Proposition & - & \\
\hline Customer & - & \\
\hline \multirow{3}{*}{ Activity } & Main Activity & \\
\hline & Channel & \\
\hline & Resources for Sharing & \\
\hline \multirow[t]{2}{*}{ Resources } & Resources for Main Activities & \\
\hline & Resources for Fostering Relati & ships \\
\hline Cost Structure & - & \\
\hline \multirow[t]{2}{*}{ Revenue Flow } & - & \\
\hline & & $\begin{array}{l}\text { 1. Coordinator with outside } \\
\text { parties }\end{array}$ \\
\hline \multirow[t]{3}{*}{ Business Actor } & Intermediaries & 2. Investor \\
\hline & & 3. Supporters \\
\hline & Relationship with Customers & $\begin{array}{l}\text { 1. Relationship with } \\
\text { Customers } \\
\text { Relationships with } \\
\text { outside parties who work } \\
\text { together }\end{array}$ \\
\hline \multirow{2}{*}{ Relation } & Relationship with & 1. Investor Relations \\
\hline & Intermediaries & $\begin{array}{l}\text { 2. Relationship with } \\
\text { Intermediaries }\end{array}$ \\
\hline
\end{tabular}

Source: Choi et al., 2014 


\section{Rimawati \& Sula \\ Strategies and Business Models of Sharing Economy: MSMEs Digital Creativity}

The data of this study were derived from the observations of the Pesan Antar business and informants' information. Informants that are selected based on the objectives of this study. The main informants of this research is Agus Josiandi, founder dan director of Pesan Antar. Based on Agus's statement, often inviting his wife in activities with the courier and Partners, so for reason to data triangulation, Atik, Agus's Wife also chosen as the informant. Other Pesan Antar personel selected as informants are Kris and Agis Teach. Kris, operator Pesan Antar. The operator is in charge as the coordinator of the courier, as well as being the mediator/liaison/customer service in every order between the courier and the customer and business partners. Actually, Kris is the fisrt employee and fisrt courier in Pesan Antar. Work in Pesan Antar is the main job Kris. Agus Teach, Pesan Antar's Couriers. Agus Teach chosen as informan because one of the "senior" couriers of Pesan Antar. As Pesan Antar's Couriers is side job Agus Teach. Agus Teach joined a Pesan Antar since September 2016. The informants chosen from partners (MSMEs) are Pawonkoe (the MSMEs exists before Pesan Antar) and Q-ta Store (the MSMEs exists after the Pesan Antar). While the informants who represent customers is Riski. Riski is the loyal costomer who have done a repeat order for at least 1 year. Riski knows the Pesan Antar from Facebook.

\section{Result and Discussion}

Agus Josiandi, the Founder and Owner of Pesan Antar, is a graduate of Bachelor's Degree of Management. Agus's business talent (Agus Josiandi's nickname) has actually been honed when he was a child. This is based on his confession who is accustomed to helping the work of his parents who have a slaughterhouse and a grocery store. While still a student, Agus had built a culinary business. But this business development was not as expected, so Agus decided to "work" as a reporter. The development of ICT has changed the way of life and offers many "new things", not least in "business". The rise of food sellers on social media, especially Facebook in Bangkalan Regency in the middle of 2016, was recognized by Agus as the initial idea of the Pesan Antar business opportunity.

"I see that in Bangkalan there are many women who have a home-based business and have the potential to develop. Especially businesses related to culinary. Many of these home-based entrepreneurs still carry out their home-based businesses offline, meaning that they are still conventional in nature. On the other hand, I see that some of these mothers already have some who use social media (generally Facebook) to simply sell their products there, advertise, and accept orders. Only I see is still not optimal. Unfortunately, because there is no accessible delivery service, the seller must also process the product delivery himself. A condition that is less effective for the business done by the seller if they have to do everything themselves from upstream to downstream. "

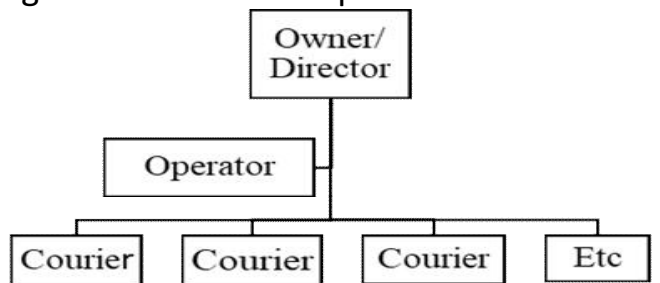

Figure 1. Organizational Structure Pesan Antar

Source: Processed Data, 2019

Jurnal IImiah Akuntansi dan Bisnis, 2020 | 191 


\section{Rimawati \& Sula \\ Strategies and Business Models of Sharing Economy: MSMEs Digital Creativity}

With the idea to "serve" this business niche (at that time in Bangkalan there was no similar delivery service or application-based transportation). Accompanied by the lack of employment in the area where he lives (Bangkalan) so that the impact on the level of unemployment, moved Agus to return to entrepreneurship.

"Beginning to start this Pesan Antar is actually because it is saturated with long work. Eager to start the entrepreneurship process at the time, but collided with minimal capital. You could say there is no capital. I also do not have special expertise, so think also at that time what kind of business is roughly right and can be run. Then I saw the potential that I knew a lot of places delicius food in Bangkalan".

At that point, Agus built a "delivery service" Business. The business is labeled "Pesan Antar". By recruiting 1 courier at the beginning of its operation, the Pesan Antar still exists today (2019) even having the onslaught of a similar business even when Grab has been operating in Bangkalan. The initial capital to build this business is "only" Rp. 500,000 on August 10, 2016. The initial capital Agus used to build "branding".

"I am determined to make business cards, delivery jackets, and transaction notes. At that time I tried to build a reputation first, even though my business had not started. I think, this kind of service that is needed first is trust, so people don't hesitate, for example, we want to use our services. Partners and customers know whom to contact if there are complaints to whom, and so on. While waiting for all the details to be there, I began to build branding with an account named Pesan Antar on social media. My focus was on Facebook at the time because it was the center of online media for the average mother there. Start many questions".

At the beginning of its establishment, the task of the operator was directly controlled by the founder of Pesan Antar. In its development, after this business has been running for three months, the operator's duty is given to one of his trusted employees. This trust employee is the first employee to join.

In its development, the organizational structure of interagency messages as shown in Figure 1. The Founder works as a "Director". The director monitors business and the quality of operator and courier services. In addition, the director is also in charge of conducting research and business development. The operator is in charge as the coordinator of the courier, as well as being the mediator/liaison/customer service in every order between the courier and the customer and business partners. Whereas the courier has the duty to take and deliver orders from business partners to customers.

"Position" operators are handed over to Kris and Banna in turn. Kris was the first "employee" that Agus recruited at the beginning of the founding of Pesan Antar. Initially Kris "worked" on the Pesan Antar as a Courier. Operator in charge of receiving orders from customers, then distribute them to the courier through the WhatsApp group. As explained by Kris:

"So, we made groub on whatsapp. All twelve workers joined the group. The first step the couriers must be absent in whatsapp group every day to start the work of this delivery. We started working at 8 am, to $7 \mathrm{pm}$. For couriers who do the first roll call, they get the task of making a delivery first. And so on in order until all the couriers get their turn. After the courier does his/her job, the courier is required to provide information to the whatsapp group and start doing the work again on condition that the task is completed first before getting the first position to deliver the customer's next order." 


\section{Rimawati \& Sula \\ Strategies and Business Models of Sharing Economy: MSMEs Digital Creativity}

As a delivery service business, the main aspect of this business is the availability of human resources of couriers. More and more couriers will accelerate and increase the number of "services" to partners and customers. During its development in the past three years, the number of couriers is now twelve with demographic levels that vary from gender, age, and education level. This amount always fluctuates, from the start this business was established with couriers entering and leaving for various reasons.

The number of couriers of Pesan Antar have fluctuations. The total number of couriers the most has ever had the Pesan Antar in three years is fifteen couriers. The majority of Pesan Antar's couriers are men. Whereas only 1 female courier. Based on the level of education, five of the courier Messengers are graduates of a University with a Diploma and Bachelor degree and the rest are high school.

According to Agus, Pesan Antar has reached the Break Event Point (BEP) in the second month after operating. Had used the payroll system at the courier at the beginning of its operation, but in the second month the Pesan Antar had changed it to a profit sharing system.

"The salary of the courier is paid monthly at that time, at the beginning of the operation. If there are tips obtained by the courier both from the seller partner (usually in the form of food sold) or the buyer (overpayment) purely the right of the courier. But at that time I started paying salaries for couriers in the second month with profit sharing."

This percentage of profit sharing has changed several times. At present, the percentage used is $85 \%$ for couriers and $15 \%$ for operations and owners. The profit sharing mechanism, even the portion of profit sharing for the courier of Pesan Antar, is not without reason, this is done to keep the motivation and loyalty of the courier when there are competitors (similar services), even at the beginning of 2019 Grab services in Bangkalan are available.

"I see the tendency of the courier to decline its performance. His work motivation has decreased. Then I replaced it with a profit sharing system of $70: 30,70 \%$ for couriers, and $30 \%$ for operational management. Using this system was effective enough to get the couriers motivated again. Then it changed again to 85:15 in the second year. Besides that I also give bonuses when reaching certain targets".

"Revenue Sharing" for operations is managed by Agus for the purchase of equipment such as transaction notes, commucation cost, operator salaries and other operational funds, and the rest is Agus's (Director) income. Agus's income actually not only came from Pesan Antar, because Agus also works as a TVRI reporter and also owns a coffee shop business. So even though the income from Pesan Antar is very minimal Agus continues to run this business. Profit sharing is proven to increase courier loyalty:

"the sharing system in the delivery order made me even more excited to work. In addition to my family's economy getting better, I also finally have many friends and can build relationships with my customers. I also become more familiar with the Bangkalan areas and new culinary places in Bangkalan."(Interviuwed Agus Teach)."

In the initial year of operation, the total receipts of "shipping costs" of Pesan Antar can reach six hundred thousand to seven hundred fifty thousand per day. With the emergence of competitors, there has been a decline in revenue in the third year. Average revenue per day can only reach five hundred thousand to six hundred thousand. 


\section{Rimawati \& Sula \\ Strategies and Business Models of Sharing Economy: MSMEs Digital Creativity}

In terms of the comparison of the number of customer services or the average order received by Pesan Antar also decreased, although the difference is not significant. In one operational year, all courier of Pesan Antar can serve orders in the range of numbers 150-250 orders, in other words if there are twelve couriers at that time, each courier can work on 12-20 customer orders a day. In this third year, the average number of orders received by couriers is around 8-17 customer orders.

The decrease in revenue and the number of customer services, apparently did not affect the number of business partners who joined the Pesan Antar. Despite the fluctuations, the total business partners are still struggling with 20-50 partners per year. Some partners are even very loyal to use the Pesan Antar service as their partner for shipping customer orders, from the very beginning operating until now even though many similar competitors have emerged. The comperation Business development of Pesan Antar when it began to operate 2016 (without competitors) with the availability of similar services in Bangkalan, especially Grab (2019) summarized in Table 2.

When viewed from the average number, the number of Pesan Antar's partners looks stagnant. From the Agus explanation, it is known that some of Pesan Antar's partners are MSMEs that do not have a place of business. This kind of MSME's business sustainability is very vulnerable to central figures. For example, if the central figure is a housewife, if she gives birth or increases domestic household activities, her business will cease.

Pesan Antar business development plan is "branding" only on the service between goods (not people), because "humanitarian" reasons. This is as stated by Agus:

"Among all the reasons, the main reason is the Pesan Antar does not want to take the "land" of pedicab, public transport, and other services related to passenger transportation. Although the concept of fortune has actually been set up, I personally do not have the heart to contribute to narrowing the workforce of others."

Referring to the way taken by Gojek, the vehicle used by the courier and its fuel costs come from the courier's personal "assets". This was explained by Kris (the operator) of the Pesan Antar when it was confirmed whether the costs of raw materials and vehicle repairs were from the company.

Table 2. The Comparison Business Development of Pesan Antar

\begin{tabular}{|c|c|c|}
\hline Business development & First Year & Third Year \\
\hline Service area coverage & Bangkalan City District & $\begin{array}{l}\text { Bangkalan City, Socah, } \\
\text { Burneh, and Kamal District }\end{array}$ \\
\hline Number of Couriers & 1 courier & 12 couriers \\
\hline $\begin{array}{l}\text { Gross Revenue for } \\
\text { management }\end{array}$ & $\begin{array}{l}\text { Rp. } 600.000 \text { to Rp. } 750.000 \\
\text { per day }\end{array}$ & $\begin{array}{l}\text { Rp. } 500.000 \text { to Rp. } 650.000 \\
\text { per day }\end{array}$ \\
\hline Profit Sharing Portions & couriers & couriers \\
\hline with courier & $\begin{array}{l}30 \% \text { for operational and } \\
\text { owner }\end{array}$ & $\begin{array}{l}15 \% \text { for operational and } \\
\text { owner }\end{array}$ \\
\hline $\begin{array}{l}\text { Total customer service } \\
\text { (average order per } \\
\text { day) }\end{array}$ & $150-250$ services & $100-200$ services \\
\hline $\begin{array}{l}\text { Number of business } \\
\text { partners }\end{array}$ & 20-50 partners & partners \\
\hline
\end{tabular}

Source: Excerpted from "Pesan Antar" Owner, 2019 


\section{Rimawati \& Sula \\ Strategies and Business Models of Sharing Economy: MSMEs Digital Creativity}

"No, unless the courier had an accident while working. But the change is not big, the biggest is usually Rp. 200,000."

For cooperation with partners, there is no "special agreement" with Pesan Antar. This collaboration starts when there are customer orders to buy or deliver goods. In addition, Pesan Antar is also active in initiating partnerships, namely "marketing products" of partners on the social media of Pesan Antar. The marketing of partner products through social media can be done by internal of Pesan Antar or as explained by Didin (owner of Q Store), Pesan Antar's partner.

"I made a product first, after that I posted on social media with the tagging of social media of Pesan Antar, then after that there was an order. Customers usually directly contact the delivery person to order the desired goods or products. Sometimes there are also customers who contact me directly to order it. However, I still confirm the delivery order also to send customer orders."

Beginning with its appearance in 2016, Pesan Antar can be said to be the pioneer of the delivery service business at that time in Bangkalan Regency (Maika, 2017) The absence of similar services, even Grab in Bangkalan recognized the owner as a distinct advantage at that time. For more than three years the Pesan Antar business has been running, it is normal for competitors to have similar services. The presence of this competitor is considered not a threat to the sustainability of the Pesan Antar, as stated directly Agus:

"There is nothing to worry about competitors. It is precisely this as a stimulant so that it can continue to improve, innovate and improve services. The presence of several similar businesses is not a strong threat to the sustainability of the Pesan Antar, given the different market segmentation ".

Courier of Pesan Antar come from various backgrounds. If looked at the level of education, all couriers must have at least a high school/equivalent degree, although this is not a requirement to be a courier of Pesan Antar. A requirement to be a courier of Pesan Antar is having a vehicle, Sim C and an android-based phone. The choice of a courier of Pesan Antar can be a main or side job. For Kris to be an operator as well as a courier is his main job and does not intend to find another job, as he expressed,

"I became an operator starting from August 2016. At that time, I was looking for job vacancies after one year of unemployment. There is no, I only work on this Pesan Antar. Because in my opinion it's not complicated and its work depends on us. If you want to reach the target you must work hard. "

In contrast to Kris, Agus Teach, one of the "senior" couriers of Pesan Antar, took this profession as a side job. The following are excerpts of an interview with Agus Teach when they were confirmed the reason for joining the Pesan Antar.

"I joined the Pesan Antar for economic reasons, because I had been married since May 2016 and my job at that time was a volunteer sports teacher at elementary school until now. My salary as a teacher is only Rp. 300,000 per month. IDR 300,000, if in Pesan Antar, I can get 2-3 days. Because I have been on a long time to order, now I have a lot of repeat customers. So a week I get an average of Rp. $600,000 . "$

In the middle of the hustle and bustle of similar services in Bangkalan, Agus maintained the loyalty of his couriers by changing the payroll system to a profit sharing system and give bonuses when reaching certain targets, as explained before. In building the Pesan Antar Business, Agus wants to be based on "partnership". The foundation of 


\section{Rimawati \& Sula \\ Strategies and Business Models of Sharing Economy: MSMEs Digital Creativity}

this partnership is both internal (management \& courier) and external (partners \& customers). So that the culture that is built is a family culture not a culture of superiors and subordinates, or bosses with workers. Agus always invited to discuss the "Team" message between to maintain business continuity. This "formal" discussion is held at Agus's Warung (Warung Bang Jos) every Monday night. This is illustrated by the following collection of interview excerpts:

"This arises from every employee, namely the high sense of solidarity and kinship among fellow employees. So when there is an employee's family sick or accident, friends immediately help and visit him to make contributions together. So when you are close and like your own family it feels really good". (Interviuwed Kris)

"Usually we hang out at the boss's shop every Monday night. The agenda is only limited to small talk, salary distribution, and complaining. Usually the boss also often gives input and motivation to me and my friends. The point is that this Pesan Antar have a strong sense of family. when one of the members was "unfortunate", we were quick to help, unless he is delivering orders. Even the boss also gives financial support even though for treatment."(Interviuwed Courier, Agus Teach)

Even to foster a sense of kinship, Agus also involved his wife (Atik). Here is Atik's explanation:

"Invited directly interact with operators, couriers, partners and customers. For example, once the wife of one of the couriers gave birth, was invited to visit her baby. There is a courier / operator who is married, invited to attend the event." \

Be a partner of Pesan Antar there are no special requirements. There is no obligation to fill out the registration form, submission of administrative documents, or other strict requirements such as Grab or Gojek. Registration is free with "just say" to the founder or operator or tag on Pesan Antar Facebook account. Even in some cases the process of cooperation into new partners Pesan Antar begins with the Pesan Antar initiative to promote partner products. As long as partners are willing to have their products "ordered" by Pesan Antar, anyone can become a business partner, including street food vendors. The following is an interview with Agus:

"I think the Pesan Antar and MSME has a kind of symbiotic mutualism relationship. So the recognition of the MSME branding that we are promoting, the hope is to become a partner at the time, although it is not a necessity. So we just introduced the MSME, and that helped people too. If you then want to be a partner and use our services, God Blassed (Alhamdulillah). If not, that's fine too. It's each person's choice. So there really was that time, what we were promoting was not wanting to use our services, the reason was complicated, and so on. Yes, we understand. But most of the ones we help promote, after that usually use the Pesar Antar service, then if you make a promotional post they tag the Pesan Antar account. Our accounts became crowded by itself because it was filled with promotional posts by partners. Maybe because of the effect of picking up the ball earlier".

The researcher confirmed the impact of the existence of Pesan Antar on the MSMEs who had become partners. The following are the results of the interview with Ms. Wiwin (owner Pawonkoe):

"Efficient in working. Now usually consumers are often lazy (lazy to move) to buy something, including myself. So when there are consumers who order to me, I can 


\section{Rimawati \& Sula \\ Strategies and Business Models of Sharing Economy: MSMEs Digital Creativity}

use this delivery service. I feel we are mutually beneficial to each other as well as symbiosis. I also use a delivery service when I want to buy kitchen needs for cooking. So it is not only used to deliver products but also buy products. Another benefit that I can feel is that my product is increasingly known to many people because Pesan Antar also help in marketing my product".

The Pesan Antar never charges fees for collaboration, so that the Partner never feels "his profit" is reduced or must provide a higher price when cooperate with Pesan Antar. The revenue received from Pesan Antar is purely from the postage paid by the customer. Cooperation is done purely as a form of symbiotic mutualism. Agus's statement is the same as the partner's statement in the interview when confirmed:

"Right, I didn't spend any money on delivery. The existence of this system is mutually beneficial. My sales are widely known among the people; this delivery service is also well known. Because I also continue to use the delivery service anywhere if there are orders from customers "(Didin, Owner of Q-ta Store).

"The Pesan Antar also promotes small traders like me. Honestly, I started this business from scratch. From me, who was at first getting a conversation now, because I had to upload my food on social media to market my product, so I learned. This Pesan Antar never asks for profit sharing from partners. Pesan Antar only gets benefits from the courier service itself. "(Wiwin, Owner Pawonkoe)

With the benefits and services felt by the Partner, growing "other things" in addition to the benefits in the relationship between Pesan Antar and Partners. As stated by Partners (Wiwin, Pawonkoe):

"Until whenever I will not be separated from the Pesan Antar. I'm not a bean that forgets its skin. I am famous and have a name too because of Pesan Antar. Pesan Antar has been very meritorious for my family's economy."

Another difference between Pesan Antar and other similar service-based businesses is determining rates. Similar services, such as Grab setting shipping rates is calculated based on kilometers traveled, where the price per kilometer is around Rp 2,500,- to Rp 3,000,- Pesan Antar actually determines rates by mapping them by region. The farther the delivery location, the rate that is set also increases but still refers to the basic rate per region. Rates in the city of $\mathrm{Rp} 5,000,-$, from the City (Bangkalan) to the neighboring Village (Burneh, Socah, Sabian) Rp 8,000,- and from the City to Kamal dan Tangkel Rp 10,000,-.

Riski, who has been using the delivery service from 2017 and knew about Pesan Antar from Facebook, explained that in addition to the rate, the reason customers choose Pesan Antar services is because of the service and the courier who "understands the field". The following are the results of the interview with:

"It's well, on time. If it's not on time the courier always gives information. In addition, even though it still rains deliver orders. Once at that time using a delivery service, then I overslept the same courier waiting in front of the house for about 30 minutes. Other courier services, in my opinion, do not yet know the location in detail in the Bangkalan area compared to the courier of interagency messages that already know a lot of Bangkalan areas. So the service is fast."

Choi et al. (2014) divide the economic sharing business model among MSMEs into 2 types. Type I is a type of shared economy in which excess goods and services are owned by anyone from outside the company and lent to the company. 
Rimawati \& Sula

Strategies and Business Models of Sharing Economy: MSMEs Digital Creativity

Table 3. Reflexivity of Pesan Antar Business Model Based on Type I Economic Sharing Business Model of MSMEs

\begin{tabular}{|c|c|}
\hline Categories & Activities \\
\hline \multirow{3}{*}{$\begin{array}{l}\text { Value } \\
\text { Proposition }\end{array}$} & 1. Food and product delivery services at affordable prices \\
\hline & $\begin{array}{l}\text { 2. Simple market place for business groups of housewives who have limited } \\
\text { capital, especially related to business locations }\end{array}$ \\
\hline & Resources for Sharing party: \\
\hline \multirow{15}{*}{ Resource } & 1. Courier \\
\hline & 2. Operator \\
\hline & 3.Partner \\
\hline & Resources for Main Activities: \\
\hline & 1. 1 unit of smartphone \\
\hline & 2. Motor cycle \\
\hline & 3. Human Resources (couriers and operators) \\
\hline & 4. Completeness of service (Box, Courier jacket, Shipment receipt) \\
\hline & Resources for Fostering Relationships: \\
\hline & 1. Each smartphone owned by the courier, operator, and owner \\
\hline & 2. Human Resources (couriers and operators) \\
\hline & 3. Business \\
\hline & 4. Partners \\
\hline & 5. Customer \\
\hline & 1. Revenue sharing by courier \\
\hline Cost & 2. Bonuses for couriers if they meet daily targets \\
\hline \multirow[t]{3}{*}{ Structure } & 3. Operational costs (credit, uniforms, memo, invoice) \\
\hline & 4. Operator salary (main and reserve) \\
\hline & 1. Profit is obtained from shipping costs for each order delivery process. \\
\hline \multirow{5}{*}{$\begin{array}{l}\text { Revenue } \\
\text { Flow }\end{array}$} & 2. Gross profit is obtained after shipping costs are reduced $85 \%$ as courier \\
\hline & $\begin{array}{l}\text { profit sharing, then operating costs are deducted } \\
\text { 3. The remaining average net profit is } 10 \% \text { of total turnover }\end{array}$ \\
\hline & 4. The average monthly turnover reaches $18-20$ million rupiah \\
\hline & Company Internal: \\
\hline & 1. Operator \\
\hline Business & 2. Courier \\
\hline \multirow[t]{3}{*}{ Actors } & Company External: \\
\hline & 1. Customers \\
\hline & 2. Partners \\
\hline
\end{tabular}

Source: Excerpted from "Pesan Antar" Owner, 2019 based Choi et al., (2014)

Whereas Type II is another type of sharing economy in which a company invests and shares with other companies goods or services that are expected to be excessive if each company has it. Based on the observations and interviews of informants, "assets" to provide services of key business not owned by the company (Pesan Antar) or the results of cooperation with other parties to provide them. Motorcycle is the courier's private property, while smartphone owned by the courier, operator, and owner. This "asset" is more owned by anyone from outside the Pesan Antar and lent to the Pesan Antar. The asset provided by the Pesan Antar management are completeness of service, consisting of: Box, Courier jacket, Shipment receipt. 


\section{Rimawati \& Sula \\ Strategies and Business Models of Sharing Economy: MSMEs Digital Creativity}

Based on these findings, this study identified an economic business model of sharing Pesan Antar match with Type I economic models sharing among MSMEs (Choi et al., 2014). Following is the reflexivity of the Pesan Antar Business model data based on Type I economic sharing models between MSMEs (Choi et al., 2014).

\section{Conclusion}

The business strategy of "Pesan Antar" in beginning the busisness is build branding for costomers trust by creating "assets" (jackets, boxes to carry good/orders, and transaction notes) even though the business has not yet begun and "post" every activity business in social media (facebook). Pesan Antar used and focused on facebook because it adjusts the target market.

When the business is running, Pesan Antar applies a strategy of maintaining loyalty of the couriers with profit sharing and bonus mechanisms. Furthermore, to maintain internal (operator and courier) and external (partners and customers) loyalty of the company, Pesan Antar implementing family culture to run business. Pesan Antar implementing strategy for maintain business growth with always promote MSMEs products (though not yet a partner) to Pesan Antar's Facebook account and no fees for being a partner of Pesan Antar. Pesan Antar Focus on goods delivery services, Pesan Antar business development plan is "branding" only on the service between goods (not people), because "humanitarian" reasons.

While the strategy is to maintain customer loyalty, Pesan Antar does not use the application, this makes operators, couriers, partners and customers more familiar with each other and loyal. According to customers, loyal couriers become the competitiveness of Pesan Antar because couriers become more familiar with the "field" and can deliver orders according to the time customers want. Pesan Antar also apply service rate based on service region. This is different from similar services, which uses rates base on distance (kilometers).

Because "Assets" to provide services of key business Pesan Antar privately owned by couriers and partners (MSMEs), are not owned by the company or the results of cooperation with other parties, it is in accordance with type I and not according to type II economic models sharing among MSMEs (Choi et al., 2014). This is a strategy business of Pesan Antar, with build capital branding in social media and without owned assets for key activities can serve customers and partners also provides profit sharing for couriers.

In the economic model of sharing among MSMEs, Choi et al., (2014), mentioned the need for an active role of the Government especially the Regional Government in mediating cooperation schemes and other benefits. Furthermore, Hendrastomo et al. (2016) and Amajida (2014) have mentioned that "security" is one of the important things for providers and users of online services. This study has not been able to present these two things at Tabel 3, Reflexivity of the Pesan Antar Business model data based on Type I economic sharing models between MSMEs Choi et al., (2014). Future studies are expected to be able to develop them by accommodating government role and security policies in their studies. 
Rimawati \& Sula

Strategies and Business Models of Sharing Economy: MSMEs Digital Creativity

\section{Acknowledgements}

This work was supported by LPPM Trunojoyo University with Mandiri Research Grant 2019.

\section{References}

Aldo, M. (2017). Mengecap Legitnya Bisnis Pesan Antar. https://www.liputan6.com/bisnis/read/2881026/mengecap-legitnya-bisnis-pesanantar

Amajida, F. D. (2014). Kreativitas Digital Dalam Masyarakat Risiko Perkotaan : Studi Tentang Ojek Online " Go-jel " Di Jakarta. INFORMASI Kajian IImu Komunikasi, 46(1), 115-128. https://doi.org/10.21831/informasi.v46i1.9657

Anwar, F., Tri, H. A., \& Rahmin, N. (2015). Internalisasi Nilai-Nilai Budaya Gorontalo "Rukuno Lo Taaliya" Dalam Penetapan Harga Jual Pada Pedagang Tradisional Di Kota Gorontalo. Jurnal Akuntansi Dan Auditing, 12(2), 89-109. https://doi.org/10.14710/jaa.v12i2.13861

BPS. (2017). Statistik Daerah Bangkalan.

Choi, H. R., Cho, M. J., Lee, K., Hong, S. G., \& Woo, C. R. (2014). The Business Model for the Sharing Economy between SMEs. WSEAS TRANSACTIONS on BUSINESS and ECONOMICS, 11(1), 625-634. https://doi.org/10.9723/jksiis.2016.21.5.041

Christian, L. Y. (2015). Pengaruh Perceived Organizational Support dan Kepemimpinan Situasional terhadap Kepuasan Kerja Karyawan pada Toko Buku Uranus. AGORA, 3(1), 442-449.

Detikfinace. (2019). Cara Daftar GO-Food Online, Biaya, dan Lama Proses. https://finance.detik.com/ekonomi-bisnis/d-4609392/cara-daftar-go-food-onlinebiaya-dan-lama-proses.

Eko, M. (2018). Dishub Agendakan Diskusi Dengan Layanan Ojek Online. http://www. bangkalankab.go.id/v4/?page=detail-berita\&id=751

Hendrastomo, G., Januarti, N. E., Pinasti, V. I. S., Aulia, M., Firman, A. T., \& Hidayat, T. T. (2016). Dilema Sosial Ojek Online (GOJEK). Fakultas Ilmu Sosial Universitas Negri Yogyakarta.

Hutabarat, D. (2018). "Sharing Economy" Tumbuh di Tengah Ketidakefisienan. https://www.kominfo.go.id/content/detail/12412/sharing-economy-tumbuh-ditengah-ketidakefisienan/0/berita_satker.

Ihsannudin. (2011). Potensi Dan Konsentrasi Sebaran Usaha Kecil Dan menengah Di Kabupaten Bangkalan. Seminar Nasional Revitalisasi Peran UMKM Dalam Pembangunan Melalui Penguatan Sektor Agroindustri.

Iqbal, M. (2011). Pengembangan Masyarakat Sebagai Upaya Pencegahan Kejahatan Di Wilayah Pengembangan Jembatan Surabaya- Madura (Aplikasi Community Development Crime Prevention). Indonesian Journal of Criminology, 7(II), 228-243.

Kamayanti, A. (2016). Metodologi Penelitian Kuantitatif Akuntansi Pengantar Religiositas Keilmuan. Yayasan Rumah Peneleh.

Maika, M. R. (2016). Model Bisnis Pembelian Kolektif (Crowdfunding) Jual Beli Salam (Pesanan) Petani Dan Warga Perumahan. Seminar Nasional Agribisnis Dan Pengembangan Ekonomi Perdesaan.

Maika, M. R. (2017). Model Ekonomi Berbagi “Mobile-Seco" (Platform Multi-Sided Markets) Sebagai Ekosistem Sosio-Ekonomi Islami. IQTISHODUNA, 1(2), 47-55. https://doi.org/10.18860/iq.v12i2.3946 
Muhktar, S., \& Muchammad, N. (2011). Peran Serta Masyarakat Bangkalan Dalam Mengusahakan Peningkatan Perekonomian. Jurnal Sosial Humaniora, 4(1), 84-95. https://doi.org/10.12962/j24433527.v4i1.641

Osterwalder, A., \& Pigneur, Y. (2010). Business Model Generation. Elex Media Komputindo.

Paquette, H. (2018). Social Media as a Marketing Tool: A Literature Review. University of Rhode Island DigitalCommons@URI. http://digitalcommons.uri.edu/tmd_major_papers

Putra, F. (2018). Sharing Economy ke Cooperative Economy. https://ekonomi.kompas.com/read/2017/10/23/070203126/dari-sharingeconomy-ke-cooperative-economy

Safira, F. (2018). he Phenomenon of Sharing Economy, Sharing or Collaborative Consumption is a form of a New Business Model that is Built Based on the Concept of Resource Sharing. https://dev.ppm-manajemen.ac.id/blog/artikel-manajemen18/post/the-phenomenon-of-sharing-economy-1255

Salim, B., \& Ihalauw, J. J. O. I. (2017). Transformasi Model Bisnis Go-jek Untuk Keuanggulan-Kompetitif Dalam Perkembangan Ekonomi-Berbagi Dari Sudut Pandang Pelanggan. Journal of Business \& Applied Management, 10(2), 106-123. https://doi.org/10.30813/jbam.v10i02.931

Setiawan, A. R. (2019). Interpretasi Baru "Malo" dan Penegakan Karakter Kejujuran: Tafsir Budaya(wan) Madura atas "Sisi Gelap" Pengelolaan Keuangan Daerah (Studi Bid'ah Hermeneutics). Jurnal Ilmiah Akuntansi Dan Bisnis, 14(2), 252-264. https://doi.org/10.24843/jiab.2019.v14.i02.p10

Suprijati, J., \& Yakin, A. (2017). Pertumbuhan Ekonomi Di Kabupaten Bangkalan Setelah Adanya Pembangunan Jembatan Suramadu (Analisi Teori Harrod-Domar). Develop, 1(1). https://doi.org/10.25139/dev.v1i1.294

Tambunan, T. (2009). Women entrepreneurship in Asian developing countries : Their development and main constraints. Journal of Development and Agricultural Economics, 1(2), 27-40.

Tjitradi, E. C. (2015). Evaluasi Dan Perancangan Model Bisnis Berdasarkan Business Model Canvas. Surabaya. Program Manajemen Bisnis, Program Studi Manajemen, Universitas Kristen Petra.

Yunus, M. (2018). Go-Jek Sebagai Simbol Perubahan Sosial Dan Ekonomi Di Kota Tegal. Equilibria Pendidikan : Jurnal Ilmiah Pendidikan Ekonomi, 2(2), 40-49. https://doi.org/10.26877/ep.v2i2.2133 